\title{
Transactions
}

Cite this: Dalton Trans., 2011, 40,6711

wWW.rsc.org/dalton

PAPER

\section{Multimetal Fischer carbene complexes of Group VI transition metals: synthesis, structure and substituent effect investigation $\dagger$}

\author{
Daniela I. Bezuidenhout,* Werner Barnard, Belinda van der Westhuizen, Elisia van der Watt and David C. Liles
}

Received 2nd February 2011, Accepted 14th April 2011

DOI: $10.1039 / \mathrm{cldt10183h}$

\begin{abstract}
Fischer carbene complexes of tungsten with substituents containing up to two additional different transition metals, with all the metals in electronic contact with the carbene carbon atom, were synthesised and studied both in solution and in the solid state. For the complexes of the type $\left[\mathrm{W}(\mathrm{CO})_{5}\left\{\mathrm{C}\left(\mathrm{OR}^{\prime}\right) \mathrm{R}\right\}\right]$, the substituents chosen were heteroaromatic 2-benzo[b]thienyl (2-BT), or 2-BT $\pi$-bonded to a chromium tricarbonyl fragment $\left(\left[\mathrm{Cr}(\mathrm{CO})_{3}\left(2-\eta^{6}-\mathrm{BT}\right)\right]\right)$ or ferrocenyl $(\mathrm{Fc})$ as the $\mathrm{R}$-substituent, while the $\mathrm{OR}^{\prime}$-substituent was systematically varied between an ethoxy or a titanoxy group, to yield the complexes $1 \mathrm{~b}\left(\mathrm{R}^{\prime}=\mathrm{Et}, \mathrm{R}=2-\mathrm{BT}\right), 2 \mathrm{~b}\left(\mathrm{R}^{\prime}=\mathrm{Et}, \mathrm{R}=\left[\mathrm{Cr}(\mathrm{CO})_{3}\left(2-\eta^{6}-\mathrm{BT}\right)\right]\right), 3 \mathrm{~b}\left(\mathrm{R}^{\prime}=\right.$ $\left.\mathrm{TiCp}_{2} \mathrm{Cl}, \mathrm{R}=21-\mathrm{BT}\right), 4 \mathrm{~b}\left(\mathrm{R}^{\prime}=\mathrm{TiCp}_{2} \mathrm{Cl}, \mathrm{R}=\left[\mathrm{Cr}(\mathrm{CO})_{3}\left(2-\eta^{6}-\mathrm{BT}\right)\right]\right), 5 \mathrm{~b}\left(\mathrm{R}^{\prime}=\mathrm{Et}, \mathrm{R}=\mathrm{Fc}\right)$ and $6 \mathrm{~b}\left(\mathrm{R}^{\prime}=\right.$ $\mathrm{TiCp}_{2} \mathrm{Cl}, \mathrm{R}=\mathrm{Fc}$ ). The structural features and their relevance to bonding in the multimetal carbene compounds of both these tungsten and the analogous chromium complexes were investigated as they represent indicators of possible reactivity sites in multimetal carbene assemblies. The possibility of using DFT calculations to quantify the effect of metal-containing substituents on the carbene ligands was tested and correlated with experimental parameters by employing methods such as vibrational spectroscopy, molecular orbital analysis, and cyclic voltammetry.
\end{abstract}

\section{Introduction}

The activation of simple organic molecules by more than one transition metal constitutes an area of research that has grown in importance. The applications of carbenes as active or auxiliary ligands in organic synthesis and catalysis, however, are mostly focused on monocarbene systems. Examples of large assemblies of carbene units (carbene supramolecular chemistry) are scarce and only a few carbene complexes are known to be part of small metal organic frameworks (MOFs). ${ }^{1}$ In fact very few studies on multimetal carbene complexes or multicarbene metal complexes have been recorded. ${ }^{2}$

The first examples of chromium Fischer carbene complexes with substituents containing an additional two transition metals, with all three metals in electronic contact with the carbene carbon atom, were synthesised in our laboratories (Fig. 1). ${ }^{3}$ Monoand dimetal substituted carbene complexes were derived from a lithiated benzothienyl substituent (2-BT) or $\left(\mathrm{Cr}(\mathrm{CO})_{3}\left(\eta^{6}-2\right.\right.$ BT)), followed by alkylation of the acyl metalate by triethyloxonium tetrafluoroborate or reaction with titanocene dichloride. The $\left[\mathrm{Cr}(\mathrm{CO})_{3}\left(\eta^{6}-2-\mathrm{BT}\right)\right]$-substituent has the $\pi$-bonded chromium tricarbonyl fragment coordinated to the ring furthest away from the carbene carbon atom, leaving an unoccupied space directly

Department of Chemistry, University of Pretoria, Private Bag X20, Hatfield, 0028, South Africa. E-mail: daniela.bezuidenhout@up.ac.za; Fax: (+27)12 420 4687; Tel: (+27)124202626

$\dagger$ CCDC reference numbers 810995-810999. For crystallographic data in CIF or other electronic format see DOI: 10.1039/c1dt10183h

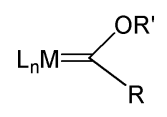

$\begin{aligned} \mathrm{ML}_{n} & =\mathrm{Cr}(\mathrm{CO})_{5}, \mathrm{Re}_{2}(\mathrm{CO})_{9} \text { or } \mathrm{MnCp}(\mathrm{CO})_{2} \\ \mathrm{R}^{\prime} & =\mathrm{TiCp}{ }_{2} \mathrm{Cl} \text { or } \mathrm{Et} \\ \mathrm{R} & =\mathrm{Fc} \text { or }\left(\eta^{6}-2-\mathrm{BT}\right) \mathrm{Cr}(\mathrm{CO})_{3}\end{aligned}$

Fig. 1 Multimetal carbene complexes of chromium.

beneath the thiophene bonded to the carbene carbon atom. This prompted the investigation into the possibility of replacing the benzothienyl fragment by a more compact, redox-active ferrocenyl substituent in order to increase the electronic communication between the $\pi$-bonded transition metal and the carbene carbon atom, as well as heteroaryl rings with the $\pi-\mathrm{Cr}(\mathrm{CO})_{3}$-moiety in closer proximity to the carbene carbon atom.

The structural features and their relevance to bonding in the polymetallic carbene compounds of the Group VI transition metals were investigated. They were correlated with spectroscopic, electrochemical and theoretical calculations, as these represent indicators of possible reactivity sites. Recently, different aspects of the nature of the metal-carbon bond in Fischer carbene complexes have been theoretically investigated by means of DFT calculations. ${ }^{4}$ Several studies have shown that the chemical reactivity of the Fischer-type carbene complexes of Group VI transitions metals, $\left[\mathrm{M}(\mathrm{CO})_{5}\{\mathrm{C}(\mathrm{X}) \mathrm{R}\}\right](\mathrm{M}=\mathrm{Cr}, \mathrm{W})$ depends mainly on the electronic characteristics of the carbene substituents $\mathrm{X}$ and $\mathrm{R}$, which seem to have remarkable control on the electrophilicity of the complex, ${ }^{5}$ where $\mathrm{X}$ is a heteroatomic substituent (ethoxy, amino or thiophenol) and $\mathrm{R}$ a heteroaromatic substituent (furyl, thienyl and $N$-methylpyrrolyl). 
It was concluded that stabilisation occurs by conjugative release of electrons from the heteroarene substituent $\mathrm{R}$ rather than specific $\pi \rightarrow p$ donation. ${ }^{6}$ Hence the electronic character of the carbene carbon atom is more strongly influenced by the $\mathrm{X}$ group than either the metal or the $\mathrm{R}$ group.

\section{Experimental}

\section{General considerations}

All operations were carried out under an inert atmosphere of nitrogen or argon gas using standard Schlenk techniques. Solvents were dried and distilled under an atmosphere of nitrogen. Diethyl ether, hexane and THF were distilled from sodium metal, with benzophenone as indicator for the ethereal solvents. Dichloromethane was distilled from phosphorous pentoxide. Most chemicals were used without prior purification, unless stated otherwise. $\mathrm{W}(\mathrm{CO})_{6}$, $\mathrm{Cr}(\mathrm{CO})_{6}$, benzo $[b]$ thiophene, ferrocene, $n$-BuLi $\left(1.6 \mathrm{~mol} \mathrm{dm}^{-3}\right.$ solution in hexane) and titanocene dichloride were used as purchased. Triethyloxonium tetrafluoroborate was prepared according to literature procedures, ${ }^{7}$ and TMEDA was distilled before use. $\left[\mathrm{Cr}\left(\eta^{6}-2-\mathrm{BT}\right)(\mathrm{CO})_{3}\right]$ was prepared from trisamine(tricarbonyl) chromium by a modified literature procedure. ${ }^{8}$ Iodoferrocene (FcI) was prepared according to Fish and Rosenblum's method. ${ }^{9}$ Column chromatography using silica gel $60(0.0063-0.200 \mathrm{~mm})$ or neutral aluminum oxide 90 as the stationary phase was used for all separations, and columns were cooled by circulating ice-water through the column jackets. Melting points were not recorded due to decomposition during heating. NMR spectra were recorded on a Bruker AVANCE 500 spectrometer. ${ }^{1} \mathrm{H}$ NMR spectra were recorded at $500.139 \mathrm{MHz}$ and ${ }^{13} \mathrm{C}$ NMR spectra at $125.75 \mathrm{MHz}$. The signal of the deuterated solvent was used as reference, e.g. ${ }^{1} \mathrm{H}$ $\mathrm{CDCl}_{3} 7.24 \mathrm{ppm}$, benzene- $d_{6} 7.15 \mathrm{ppm}$ and ${ }^{13} \mathrm{CCDCl}_{3} 77.00 \mathrm{ppm}$, benzene- $d_{6} 128.00 \mathrm{ppm}$. FAB-MS spectra were recorded on a VG 70SEQ Mass Spectrometer, with the resolution for $\mathrm{FAB}=1000$ in a field of $8 \mathrm{kV}$. Nitrobenzyl alcohol was used as the solvent and as the internal standard.

\section{Synthesis of 1-6}

The general method for the synthesis of the chromium carbene complexes as described before ${ }^{3}$ was employed to prepare the tungsten analogues (Scheme 1). The ferrocenyl ethoxycarbene complexes of both chromium and tungsten (5a and $\mathbf{5 b}$ ) are known, and their structures have been reported. ${ }^{10}$ The relevant (hetero)arene (benzo[b]thiophene, $\left[\mathrm{Cr}(\mathrm{CO})_{3}\left(\eta^{6}-2-\mathrm{BT}\right)\right]$ or $\mathrm{FcI}$ ) $(5 \mathrm{mmol})$ was stirred while adding $n$-BuLi $(5.5 \mathrm{mmol}, 1.5 \mathrm{M}$, $3.66 \mathrm{~mL}$ ) in $40 \mathrm{~mL}$ of THF at $-20^{\circ} \mathrm{C}$ under an inert $\mathrm{N}_{2}$ atmosphere. Stirring was continued for $2 \mathrm{~h}$. $\left[\mathrm{W}(\mathrm{CO})_{6}\right](5 \mathrm{mmol})$ was added at $-78{ }^{\circ} \mathrm{C}$, resulting in the reaction mixture changing to a darker colour, while stirring for $1 \mathrm{~h}$. Stirring was then continued for an additional $30 \mathrm{~min}$ at RT. THF solvent was evaporated under reduced pressure. $\mathrm{Et}_{3} \mathrm{OBF}_{4}(6 \mathrm{mmol}, 1.15 \mathrm{~g})$ or $\mathrm{TiCp}_{2} \mathrm{Cl}_{2}(6 \mathrm{mmol}$, $1.49 \mathrm{~g}$ ) in dichloromethane was added to the reaction mixture at $-30{ }^{\circ} \mathrm{C}$ and stirred until reaction completion. $\mathrm{LiBF}_{4} / \mathrm{LiCl}$ salts were removed by filtration and the reaction products were separated by column chromatography using hexane/dichloromethane $(4: 1)$ as the eluent. The products were recrystallised by solvent layering using hexane/dichloromethane $(1: 1)$. The atom number-

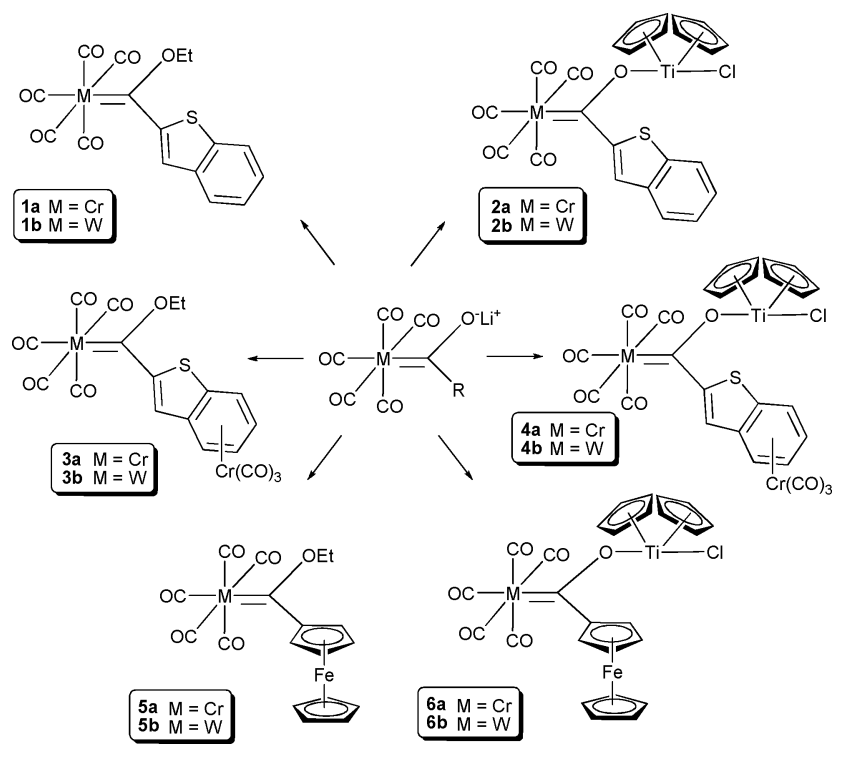

Scheme 1

ing system employed in the NMR assignments is given in Fig. 2. No ${ }^{13} \mathrm{C}$ NMR spectra could be obtained for $3 \mathbf{b}$ and $\mathbf{4 b}$ due to the decomposition of these complexes in solution over the long accumulation times required for recording of these complexes' NMR spectra.
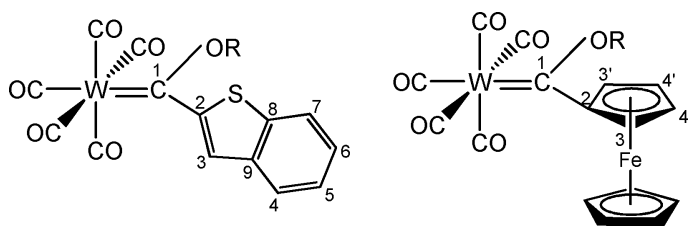

Fig. 2 Atom numbering system used for NMR spectral data.

$\left[\mathrm{W}(\mathrm{CO})_{5}\{\mathrm{C}(\mathrm{OEt})(2-\mathrm{BT})\}\right]$ (1) $)$ (abbreviated as WBTEt): yield $1.75 \mathrm{~g}(68 \%)$, red-brown crystals. Anal. found (calc. for $\mathrm{C}_{16} \mathrm{H}_{10} \mathrm{O}_{6} \mathrm{SW}$ ): C 37.78 (37.38), H 2.00 (1.96)\%. NMR, $500 \mathrm{MHz}$ $\left(\mathrm{CDCl}_{3}\right) ;{ }^{1} \mathrm{H}: 8.39$ (s, $\left.1 \mathrm{H}, \mathrm{H} 3\right), 7.79$ (d, $\left.1 \mathrm{H}, \mathrm{H} 4, J=8.2 \mathrm{~Hz}\right) 7.50$ $(\mathrm{m}, 1 \mathrm{H}, \mathrm{H} 5, J=8.2 \mathrm{~Hz}), 7.39(\mathrm{~m}, 1 \mathrm{H}, \mathrm{H} 6,7.9 \mathrm{~Hz}), 8.00(\mathrm{~d}, 1 \mathrm{H}$, $\mathrm{H} 7, J=7.9 \mathrm{~Hz}), 5.04\left(\mathrm{q}, 2 \mathrm{H}, \mathrm{CH}_{2}, J=6.9 \mathrm{~Hz}\right), 1.69\left(\mathrm{t}, 3 \mathrm{H}, \mathrm{CH}_{3}\right.$, $J=6.9 \mathrm{~Hz}) ;{ }^{13} \mathrm{C}: 294(\mathrm{C} 1), 198\left(\mathrm{CO}_{\text {cis }}\right.$, satellites $), 203\left(\mathrm{CO}_{\text {trans }}\right), 157$ (C2), 142 (C3), 123 (C4), 129 (C5), 125 (C6), 127 (C7), 139.0, 139.5 (C8, C9), $79\left(\underline{\mathrm{CH}}_{2}\right), 14.9\left(\underline{\mathrm{CH}}_{3}\right) ;{ }^{1} \mathrm{H}\left(\mathrm{C}_{6} \mathrm{D}_{6}\right): 8.40(\mathrm{~s}, 1 \mathrm{H}, \mathrm{H} 3), 7.31$ $(\mathrm{d}, 1 \mathrm{H}, \mathrm{H} 4, J=8.1 \mathrm{~Hz}) 7.01(\mathrm{~m}, 1 \mathrm{H}, \mathrm{H} 5, J=8.1 \mathrm{~Hz}), 6.94(\mathrm{~m}, 1 \mathrm{H}$, $\mathrm{H6}, 8.1 \mathrm{~Hz}), 7.45(\mathrm{~d}, 1 \mathrm{H}, \mathrm{H} 7, J=8.1 \mathrm{~Hz}), 4.51\left(\mathrm{q}, 2 \mathrm{H}, \mathrm{CH}_{2}, J=\right.$ $7.0 \mathrm{~Hz}), 1.02$ (t, $3 \mathrm{H}, \mathrm{CH}_{3}, J=7.0 \mathrm{~Hz}$ ). IR, $v(\mathrm{CO})$ (hexane) 2067 $\mathrm{m}\left(\mathrm{A}_{1}{ }^{2}\right), 1981 \mathrm{vw}(\mathrm{B}), 1955 \mathrm{~s}\left(\mathrm{~A}_{1}{ }^{1}\right), 1945$ vs. (E). UV $\left(\mathrm{CH}_{2} \mathrm{Cl}_{2}\right) 334$ $\left(\mathrm{L}: \pi \rightarrow \pi^{*}\right), 458(\mathrm{M} \rightarrow \mathrm{L})$. FAB-MS; $m / z=514\left(\mathrm{M}^{+}\right)$.

$\left[\mathrm{W}(\mathrm{CO})_{5}\left\{\mathrm{C}\left(\mathrm{OTiCp} \mathrm{p}_{2} \mathrm{Cl}\right)(2-\mathrm{BT})\right\}\right](\mathbf{2 b})$ (abbreviated as WBTTi): yield $1.71 \mathrm{~g},(49 \%)$, red-orange crystals. Anal. found (calc. for $\mathrm{C}_{24} \mathrm{H}_{15} \mathrm{O}_{6} \mathrm{SClTiW}$ ): C 41.39 (41.26), H $2.22(2.16) \%$. NMR, 500 $\mathrm{MHz}\left(\mathrm{CDCl}_{3}\right) ;{ }^{1} \mathrm{H}: 8.35$ (s, $\left.1 \mathrm{H}, \mathrm{H} 3\right), 7.85(\mathrm{dd}, 1 \mathrm{H}, \mathrm{H} 4, J=8.1$, $1.8 \mathrm{~Hz}) 7.52(\mathrm{~m}, 1 \mathrm{H}, \mathrm{H} 5, J=8.1 \mathrm{~Hz}), 7.44(\mathrm{~m}, 1 \mathrm{H}, \mathrm{H} 6,7.9,1.8 \mathrm{~Hz})$, 8.03 (d, $1 \mathrm{H}, \mathrm{H} 7, J=7.9 \mathrm{~Hz}), 6.55$ (s, $10 \mathrm{H}, \mathrm{Cp}) ;{ }^{13} \mathrm{C}$ : n.o. (C1), 199 $\left(\mathrm{CO}_{\text {cis }}\right), 204\left(\mathrm{CO}_{\text {trans }}\right), 141(\mathrm{C} 2), 139(\mathrm{C} 3), 123(\mathrm{C} 4), 128$ (C5), 126 (C6), n.o., n.o. (C8, C9), 119 (Cp).); ${ }^{1} \mathrm{H}\left(\mathrm{C}_{6} \mathrm{D}_{6}\right)$ : 8.56 (s, $\left.1 \mathrm{H}, \mathrm{H} 3\right)$, $7.48(\mathrm{~d}, 1 \mathrm{H}, \mathrm{H} 4, J=8.3 \mathrm{~Hz}) 7.00(\mathrm{~m}, 1 \mathrm{H}, \mathrm{H} 5, J=8.3 \mathrm{~Hz}), 7.10$ (m, 1H, H6, $J=7.8 \mathrm{~Hz}), 7.52(\mathrm{~d}, 1 \mathrm{H}, \mathrm{H} 7, J=7.8 \mathrm{~Hz}), 5.87$ (s, 
10H, Cp). IR, $v(\mathrm{CO})$ (hexane): $2050 \mathrm{~m}\left(\mathrm{~A}_{1}{ }^{2}\right), 2000 \mathrm{vw}(\mathrm{B}), 1982$ vs $\left(\mathrm{A}_{1}{ }^{1}\right), 1938$ vs, $1911 \mathrm{~s}(\mathrm{E})$. UV $\left(\mathrm{CH}_{2} \mathrm{Cl}_{2}\right): 334,381\left(\mathrm{~L}: \pi \rightarrow \pi^{*}\right)$, $483(\mathrm{M} \rightarrow \mathrm{L})$. FAB-MS; $m / z=699\left(\mathrm{M}^{+}\right)$.

$\left[\mathrm{W}(\mathrm{CO})_{5}\left\{\mathrm{C}(\mathrm{OEt})\left(\left(\eta^{6}-2-\mathrm{BT}\right) \mathrm{Cr}(\mathrm{CO})_{3}\right)\right\}\right] \quad(3 \mathbf{b})$ (abbreviated as WBTCrEt): yield $1.63 \mathrm{~g}(24 \%)$, dark brown crystals. Anal. found (calc. for $\mathrm{C}_{19} \mathrm{H}_{10} \mathrm{O}_{9} \mathrm{SCrW}$ ): C 35.83 (35.10), $\mathrm{H} 1.65$ (1.55)\%. NMR, $500 \mathrm{MHz}\left(\mathrm{CDCl}_{3}\right) ;{ }^{1} \mathrm{H}: 8.05(\mathrm{~s}, 1 \mathrm{H}, \mathrm{H} 3), 6.07(\mathrm{~d}, 1 \mathrm{H}, \mathrm{H} 4, J=$ $6.7 \mathrm{~Hz}) 5.64(\mathrm{~m}, 1 \mathrm{H}, \mathrm{H} 5), 5.25(\mathrm{~m}, 1 \mathrm{H}, \mathrm{H} 6, J=6.5 \mathrm{~Hz}), 6.29(\mathrm{dd}$, $1 \mathrm{H}, \mathrm{H} 7, J=6.5 \mathrm{~Hz}), 4.98\left(\mathrm{q}, 2 \mathrm{H}, \mathrm{CH}_{2}, J=7.1 \mathrm{~Hz}\right), 1.67(\mathrm{t}, 3 \mathrm{H}$, $\left.\mathrm{CH}_{3}, J=7.1 \mathrm{~Hz}\right)$.); ${ }^{1} \mathrm{H}\left(\mathrm{C}_{6} \mathrm{D}_{6}\right): 7.91$ (s, $\left.1 \mathrm{H}, \mathrm{H} 3\right), 5.00$ (d, 1H, H4, $J=7.0 \mathrm{~Hz}) 4.56(\mathrm{~m}, 1 \mathrm{H}, \mathrm{H} 5, J=7.0 \mathrm{~Hz}), 4.17(\mathrm{~m}, 1 \mathrm{H}, \mathrm{H} 6, J=$ $6.5 \mathrm{~Hz}), 5.14(\mathrm{~d}, 1 \mathrm{H}, \mathrm{H} 7, J=6.5 \mathrm{~Hz}), 4.34\left(\mathrm{q}, 2 \mathrm{H}, \mathrm{CH}_{2}, J=7.0 \mathrm{~Hz}\right)$, $0.94\left(\mathrm{t}, 3 \mathrm{H}, \mathrm{CH}_{3}, J=7.0 \mathrm{~Hz}\right)$; IR $v(\mathrm{CO})$ (hexane): $\mathrm{W}(\mathrm{CO})_{5}: 2067$ m $\left(\mathrm{A}_{1}{ }^{2}\right), 1980 \mathrm{vw}(\mathrm{B}), 1954 \mathrm{~s}\left(\mathrm{~A}_{1}{ }^{1}\right), 1945$ vs $(\mathrm{E}) \cdot \mathrm{Cr}(\mathrm{CO})_{3}: 1945$ vs $\left(\mathrm{A}_{1}\right), 1907 \mathrm{~s}(\mathrm{E})$. UV $\left(\mathrm{CH}_{2} \mathrm{Cl}_{2}\right) 325\left(\mathrm{~L}: \pi \rightarrow \pi^{*}\right), 449,59(\mathrm{M} \rightarrow \mathrm{L})$. FAB-MS; $m / z=650\left(\mathrm{M}^{+}\right)$.

$\left[\mathrm{W}(\mathrm{CO})_{5}\left\{\mathrm{C}\left(\mathrm{OTiCp} \mathrm{Cl}_{2} \mathrm{Cl}\right)\left(\left(\eta^{6}-2-\mathrm{BT}\right) \mathrm{Cr}(\mathrm{CO})_{3}\right)\right\}\right]$ (4b) (abbreviated as WBTCrTi): yield $1.54 \mathrm{~g},(37 \%)$, purple crystals. Anal. found (calc. for $\mathrm{C}_{27} \mathrm{H}_{15} \mathrm{O}_{9} \mathrm{SClTiCrW}$ ): C 39.03 (38.85), $\mathrm{H} 1.76$ (1.81)\%. $\mathrm{NMR}, 500 \mathrm{MHz}\left(\mathrm{C}_{6} \mathrm{D}_{6}\right) ;{ }^{1} \mathrm{H}: 7.95(\mathrm{~d}, 1 \mathrm{H}, \mathrm{H} 3, J=0.8 \mathrm{~Hz}), 5.11(\mathrm{~d}$, $1 \mathrm{H}, \mathrm{H} 4, J=6.7 \mathrm{~Hz}), 4.57$ (m, 1H, H5), 4.15 (m, 1H, H6), 5.21 (dd, $1 \mathrm{H}, \mathrm{H} 7, J=6.7,0.8 \mathrm{~Hz}), 5.88,5.85$ (Cp's); IR, v(CO) (hexane): $2060 \mathrm{~m}, 1969$ s, 1930 vs, 1900 s. UV $\left(\lambda \mathrm{nm}^{-1}, \mathrm{CH}_{2} \mathrm{Cl}_{2}\right) 325(\mathrm{~L}: \pi \rightarrow$ $\left.\pi^{*}\right), 494,57(\mathrm{M} \rightarrow \mathrm{L})$. FAB-MS; $m / z=844\left(\mathrm{M}^{+}\right)$.

$\left[\mathrm{W}(\mathrm{CO})_{5}\{\mathrm{C}(\mathrm{OEt}) \mathrm{Fc}\}\right](\mathbf{5 b})$ (abbreviated as WFcEt): yield $2.35 \mathrm{~g}$ $(83 \%)$, dark brown crystals. Anal. found (calc. for $\mathrm{C}_{18} \mathrm{H}_{14} \mathrm{O}_{6} \mathrm{FeW}$ ): C 37.98 (38.20), H 2.50 (2.49)\%. NMR, $500 \mathrm{MHz}\left(\mathrm{C}_{6} \mathrm{D}_{6}\right) ;{ }^{1} \mathrm{H}$ : 4.78 (dd, 2H, H3, H3', $J=2.2,1.8 \mathrm{~Hz}$ ), 4.27 (dd, 2H, H4, H4', $J=$ 2.3,1.7 Hz) 3.92 (s, 5H, Fe-Cp), 4.49 (q, 2H, $\left.\mathrm{CH}_{2}, J=7.0 \mathrm{~Hz}\right), 0.96$ (t, $\left.3 \mathrm{H}, \mathrm{CH}_{3}, J=7.0 \mathrm{~Hz}\right) ;{ }^{13} \mathrm{C}: 303(\mathrm{C} 1), 191\left(\mathrm{CO}_{\text {cis }}\right), 198\left(\mathrm{CO}_{\text {trans }}\right)$, n.o. (C2), 74 (C3,C3'), 71 (C4,C4'), 68 (Fe-Cp), $78\left(\right.$ CH$\left._{2}\right), 15$ $\left(\mathrm{CH}_{3}\right)$; IR $v(\mathrm{CO})$ (hexane): $2065 \mathrm{w}\left(\mathrm{A}_{1}{ }^{2}\right), 1975 \mathrm{w}\left(\mathrm{B}\right.$ and $\left.\mathrm{A}_{1}{ }^{1}\right), 1927$ $\mathrm{s}(\mathrm{E})$. FAB-MS; $m / z=566\left(\mathrm{M}^{+}\right)$.

$\left[\mathrm{W}(\mathrm{CO})_{5}\left\{\mathrm{C}\left(\mathrm{OTiCp} \mathrm{p}_{2} \mathrm{Cl}\right) \mathrm{Fc}\right\}\right](\mathbf{6 b})$ (abbreviated as WFcTi): yield $2.51 \mathrm{~g}(67 \%)$, brown-purple crystals. Anal. found (calc. for $\mathrm{C}_{26} \mathrm{H}_{19} \mathrm{O}_{6} \mathrm{ClTiFeW}$ ): C 41.28 (41.26), H 2.47 (2.55)\%. NMR, 500 $\mathrm{MHz}\left(\mathrm{CDCl}_{3}\right)$; ${ }^{1} \mathrm{H}: 6.46$ (s, 10H, Ti-Cp), 5.04 (br d, 2H, H3, H3'), 4.68 (br d, 2H, H4,H4'), 4.29 (s, 5H, Fe-Cp); ${ }^{13} \mathrm{C}: 301$ (C1), 191 $\left(\mathrm{CO}_{\text {cis }}\right), 200\left(\mathrm{CO}_{\text {trans }}\right), 119,118\left(\mathrm{Ti}-\mathrm{Cp}_{2}\right)$, n.o. $(\mathrm{C} 2), 74\left(\mathrm{C} 3, \mathrm{C} 3^{\prime}\right), 70$ (C4,C4'), 70 (Fe-Cp); IR v(CO) (hexane): $2052 \mathrm{~m}\left(\mathrm{~A}_{1}{ }^{2}\right), 1958 \mathrm{~m}$ (B and $\left.\mathrm{A}_{1}{ }^{1}\right), 1916$ vs (E). FAB-MS; $m / z=750\left(\mathrm{M}^{+}\right)$.

\section{Crystal structure determination}

Single crystals suitable for data collection were obtained for $\mathbf{1 b}-\mathbf{4 b}$ and $\mathbf{6 b}$. Crystallographic and structure refinement data are given in Table 1. The X-ray crystal structure analyses were performed using data collected at $20^{\circ} \mathrm{C}$ on a Siemens $\mathrm{P} 4$ diffractometer fitted with a Bruker $1 \mathrm{~K} \mathrm{CCD}$ detector using graphite-monochromated, Mo-K $\alpha$ radiation by means of a combination of phi and omega scans. Data reductions were performed using SAINT $+{ }^{11}$ and the intensities were corrected for absorption using SADABS. ${ }^{11}$ The structures were solved by direct methods using SHELXTS ${ }^{11}$ and refined by full-matrix least squares using SHELXTL ${ }^{11}$ and SHELXL-97. ${ }^{12}$ In the structure refinements all hydrogen atoms were included in calculated positions and treated as riding on the atom to which they are attached. All non-hydrogen atoms (except for the minor occupied sites of disordered atoms) were refined with anisotropic displacement parameters. All isotropic displacement parameters for hydrogen atoms were calculated as $X \times U_{\text {eq }}$ of the

Table 1 Crystallographic and structure refinement data for the tungsten carbene complexes

\begin{tabular}{|c|c|c|c|c|c|}
\hline Complex & $1 \mathbf{b}$ & $2 \mathbf{b}$ & $3 \mathbf{b}$ & $4 \mathbf{b}$ & $6 \mathbf{b}$ \\
\hline Chemical formula & $\mathrm{C}_{16} \mathrm{H}_{10} \mathrm{O}_{6} \mathrm{SW}$ & $\mathrm{C}_{24} \mathrm{H}_{15} \mathrm{ClO}_{6} \mathrm{STiW} \mathrm{CH} \mathrm{Cl}_{2}$ & $\mathrm{C}_{19} \mathrm{H}_{10} \mathrm{CrO}_{9} \mathrm{SW}$ & $\begin{array}{l}\mathrm{C}_{27} \mathrm{H}_{15} \mathrm{ClCrO}_{9} \mathrm{STiW} \\
\mathrm{CH}_{2} \mathrm{Cl}_{2}\end{array}$ & $\mathrm{C}_{26} \mathrm{H}_{19} \mathrm{ClFeO}_{6} \mathrm{TiW}$ \\
\hline $\mathrm{MW} \mathrm{g}^{-1} \mathrm{~mol}^{-1}$ & 514.15 & 783.55 & 650.18 & 919.58 & 750.46 \\
\hline Crystal system & Monoclinic & Triclinic & Triclinic & Monoclinic & Orthorhombic \\
\hline Space group & $P 2_{1} / m$ & $P \overline{1}$ & $P \overline{1}$ & $P 2_{1} / c$ & $P n a 2_{1}$ \\
\hline$a / \AA$ & $9.3964(6)$ & $11.3533(6)$ & $8.4597(6)$ & $11.2280(5)$ & $23.220(3)$ \\
\hline$b / \AA ̊$ & $7.7430(5)$ & $11.6696(6)$ & $10.8010(8)$ & $12.2398(5)$ & $10.0663(14)$ \\
\hline$c / \AA$ & $12.5316(7)$ & $12.3627(7)$ & $13.1159(10)$ & $23.9446(11)$ & $10.8634(15)$ \\
\hline$\alpha\left(^{\circ}\right)$ & 90 & $66.392(1)$ & $109.659(1)$ & 90 & 90 \\
\hline$\beta\left(^{\circ}\right)$ & $104.757(1)$ & $88.689(1)$ & $108.080(1)$ & $101.298(1)$ & 90 \\
\hline$\gamma\left({ }^{\circ}\right)$ & 90 & $66.317(1)$ & $95.910(1)$ & 90 & 90 \\
\hline Volume $/ \AA^{3}$ & $881.68(9)$ & $1355.73(13)$ & $1043.68(13)$ & $3226.9(2)$ & $2539.2(6)$ \\
\hline Z & 2 & 2 & 2 & 4 & 4 \\
\hline$d_{\mathrm{c}} / \mathrm{Mg} \mathrm{m}^{-3}$ & 1.937 & 1.919 & 2.069 & 1.893 & 1.963 \\
\hline$\mu / \mathrm{mm}^{-1}$ & 6.696 & 4.945 & 6.176 & 4.491 & 5.535 \\
\hline$\Theta /^{\circ}$ & 2.44 to 26.54 & 2.46 to 26.57 & 2.55 to 26.61 & 2.40 to 26.56 & 2.57 to 26.43 \\
\hline Crystal size/mm & $0.24 \times 0.22 \times 0.11$ & $0.32 \times 0.30 \times 0.26$ & $0.34 \times 0.18 \times 0.08$ & $0.20 \times 0.18 \times 0.06$ & $0.22 \times 0.18 \times 0.01$ \\
\hline Index ranges & $\begin{array}{l}-10 \leq h \leq 11 \\
-9 \leq k \leq 3 \\
-15 \leq l \leq 14\end{array}$ & $\begin{array}{l}-13 \leq h \leq 13 \\
-4 \leq k \leq 14 \\
-13 \leq l \leq 14\end{array}$ & $\begin{array}{l}-8 \leq h \leq 10 \\
-6 \leq k \leq 13 \\
-15 \leq l \leq 14\end{array}$ & $\begin{array}{l}-14 \leq h \leq 13 \\
-15 \leq k \leq 4 \\
-29 \leq l \leq 29\end{array}$ & $\begin{array}{l}-28 \leq h \leq 13 \\
-11 \leq k \leq 12 \\
-12 \leq l \leq 11\end{array}$ \\
\hline Reflections collected & 4807 & 7350 & 5686 & 17325 & 12791 \\
\hline Independent reflections & 1805 & 4908 & 3784 & 6124 & 4518 \\
\hline$R_{\text {int }}$ & 0.0273 & 0.0165 & 0.0305 & 0.0248 & 0.0616 \\
\hline Parameters & 134 & 334 & 290 & 419 & 325 \\
\hline$R_{1}\left(I_{0}>2 \sigma I_{0}\right)$ & 0.0237 & 0.0264 & 0.0444 & 0.0307 & 0.0413 \\
\hline $\mathrm{w} R_{2}$ (all data) & 0.0630 & 0.0709 & 0.1172 & 0.0871 & 0.0996 \\
\hline $\begin{array}{l}\text { Absolute structure (Flack) } \\
\text { parameter }\end{array}$ & & & & & $0.027(14)$ \\
\hline
\end{tabular}


atom to which they are attached, $X=1.5$ for methyl hydrogens and 1.2 for all other hydrogens. Crystallographic and structure refinement data are given in Table 1. In the structure of $\mathbf{3 b}$ some disorder of the thienyl ring was observed with a minor orientation (sof $=0.156(7)$ ) arising from an alternate conformer of the $\eta^{6}$ tricarbonylchromium-benzo[ $b]$ thien-2-yl group with the thienyl ring rotated c.a. $180^{\circ}$ with respect to the $\eta^{6}$-tricarbonylchromiumbenzine moiety. The parameters for the major orientations were refined freely. The minor orientation atoms $\mathrm{S}(1 \mathrm{a})$ and $\mathrm{C}(8 \mathrm{a})$ $\mathrm{H}(8 \mathrm{a})$ were refined with isotropic displacement parameters and with the bond lengths to neighbouring atoms constrained to approximately equal the corresponding bond lengths in the major orientation. Two site occupation factors, one for the major orientation positions $\mathrm{S}(1), \mathrm{C}(8)$ and $\mathrm{H}(8)$ and one for the minor orientation positions $\mathrm{S}(1 \mathrm{a}), \mathrm{C}(8 \mathrm{a})$ and $\mathrm{H}(8 \mathrm{a})$, were refined but constrained to sum to 1.0 .

\section{Vibrational spectroscopy}

Solution IR spectra were recorded on a Perkin-Elmer Spectrum RXI FT-IR spectrophotometer with dichloromethane as the solvent. Only the vibration bands in the carbonyl-stretching region (ca. 1600-2200 $\mathrm{cm}^{-1}$ ) were recorded for the solution IR. Solid state Fourier Transform infrared (FTIR) spectra were obtained under vacuum as a 1\% w/w CsI disk using a Bruker IFS 113 spectrometer over the region $125-4000 \mathrm{~cm}^{-1}$ with a spectral resolution of $4 \mathrm{~cm}^{-1}$. OPUS 5.5 software was used for data processing. Experimental solid-state Raman spectra were obtained using a dispersive Raman spectrometer. All dispersive spectra were obtained by exciting the samples with the $647.1 \mathrm{~nm}$ (red) line of a Spectraphysics 5012 Krypton-ion laser. For the solid-state spectra, an Olympus confocal microscope with a 50× objective was used to focus the laser light on the sample. The scattered light was dispersed and recorded by means of a Dilor XY multichannel Raman spectrometer equipped with a liquid nitrogen-cooled Wright Generation 1 CCD detector. A Linkam RMS 90 cell was employed to obtain the solid-state Raman spectrum for all the complexes measured at non-ambient conditions of $-196{ }^{\circ} \mathrm{C}$, as degradation of the samples was seen at room temperature. All Raman spectra were obtained from the same samples as used for solid state FTIR: as CsI pellets, to allow heat dissipation by the CsI matrix. The spectral resolution was $3 \mathrm{~cm}^{-1}$, while laser output power at the source $(300-500 \mathrm{~mW})$ and integration times $(30$ $120 \mathrm{~s})$ were varied to obtain the best possible spectra. Three to four spectral accumulations were averaged, and the software used for data processing was Labspec 3.03.

\section{Computational details}

The calculations reported were obtained with the GAUSSIAN 03 suite of programmes. ${ }^{15}$ Each complex was modelled using spin restricted DFT wavefunctions (RB3LYP) ${ }^{16}$ with effective core potentials basis set LANL2DZ. ${ }^{17}$ No symmetry constraints were applied and only the default convergence criteria were used during the geometric optimizations. The complexes were all modelled in the singlet spin state and the optimized structures were confirmed to be minima energy conformations as the vibrational frequency analysis $^{18}$ yielded no imaginary frequencies. RMS deviations between the optimized molecular structures and the crystal structures using the non-hydrogen atoms were calculated with the 'RMS Compare Structures' utility in CHEMCRAFT Version 1.5. ${ }^{19}$ Good agreements between experimental and theoretical structures were obtained, reflected by RMSD values in the range of $0.10-0.16 \AA$ for the chromium complexes, and $0.06-0.19 \AA$ for the tungsten complexes.

\section{Electrochemical studies}

Voltammetric experiments were performed under a blanket of nitrogen that was saturated with solvent. The electrolyte was $0.10 \mathrm{M} \mathrm{Bu}_{4} \mathrm{NPF}_{6}$, which was synthesised by metathesis of $\mathrm{Bu}_{4} \mathrm{Br}$ and $\mathrm{HPF}_{6}$, recrystallised from dichloromethane/hexane, and dried under vacuum. HPLC grade dichloromethane was used as the solvent in all experiments. Once opened, the solvent was kept under argon and contact with the atmosphere was minimised. Additional purification was not deemed necessary or desirable. Cyclic voltammetry was carried out with EG\&G 173/175/179 potentiostatic instrumentation. The working electrode was a $1 \mathrm{~mm}$ diameter platinum disk, and the counter electrode was a platinum wire. The reference was a Metrohm $\mathrm{Ag} / \mathrm{AgCl}$ electrode filled with dichloromethane $/ \mathrm{Bu}_{4} \mathrm{NPF}_{6}$ and saturated with $\mathrm{LiCl}$; this was separated from the test solution by a salt bridge containing $0.10 \mathrm{M}$ $\mathrm{Bu}_{4} \mathrm{NPF}_{6}$ in $\mathrm{CH}_{2} \mathrm{Cl}_{2}$.

\section{Results and discussion}

\section{Molecular structures}

The crystallographic molecular structures of $\mathbf{1 b}-\mathbf{4 b}$ and $\mathbf{6 b}$, are shown in Fig. 3-7 together with the atom numbering schemes used for the structural data.

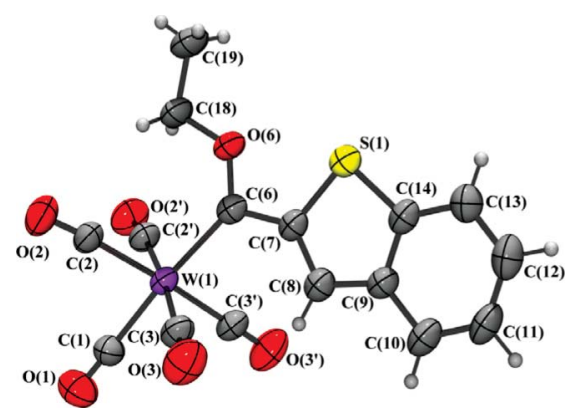

Fig. 3 ORTEP ${ }^{13}+$ POV-Ray $^{14}$ drawing of the molecular structure of $\mathbf{1 b}$. Atomic displacement ellipsoids are shown at the $50 \%$ probability level.

As observed for the chromium complexes, ${ }^{3}$ the thienyl and the ferrocenyl cyclopentadienyl ring are approximately coplanar with the carbene moiety $(\mathrm{W}(1), \mathrm{C}(6), \mathrm{O}(6), \mathrm{C}(7))$, with torsion angles $\mathrm{W}(1)-\mathrm{C}(6)-\mathrm{C}(7)-\mathrm{S}(1) / \mathrm{C}(11)$ ranging from $165.5(2)^{\circ}$ to $180.0^{\circ}$, thus allowing resonance stabilisation between the carbene ligand and the adjacent ring. The most significant features of the structures are the long $\mathrm{Ti}(1)-\mathrm{O}(6)$ bond lengths of $\mathbf{2 b}(1.931(2) \AA)$, $\mathbf{4 b}(1.921(3) \AA)$ and $\mathbf{6 b}(1.901(6) \AA)$, compared to that of typical terminal titanium(IV) alkoxides $\left(1.855 \AA\right.$ in $\left[\mathrm{TiCp}_{2}(\mathrm{OEt}) \mathrm{Cl}\right] .{ }^{20} \mathrm{The}$ very short $\mathrm{C}(6)-\mathrm{O}(6)$ bond distances of these complexes (1.279(4), $1.280(5)$ and $1.273(11) \AA$, respectively), as well as the near-linear bond angles for $\mathrm{C}(6)-\mathrm{O}(6)-\mathrm{Ti}(1)\left(171.7(3), 174.6(3)\right.$ and $175.4(7)^{\circ}$, respectively), is indicative of $\mathrm{O}(6) \rightarrow \mathrm{C}(6) \pi$-donation occurring at 


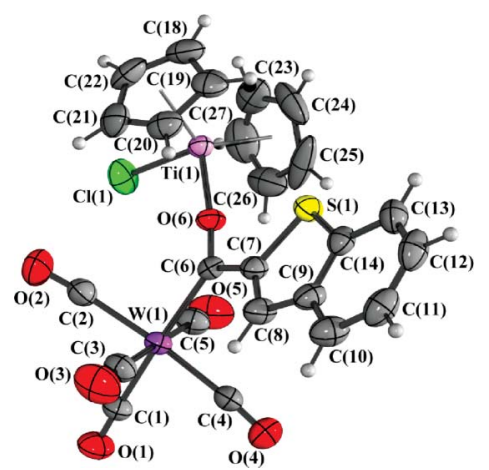

Fig. 4 ORTEP ${ }^{13}+$ POV-Ray ${ }^{14}$ drawing of the molecular structure of $\mathbf{2 b}$. Atomic displacement ellipsoids are shown at the $50 \%$ probability level.

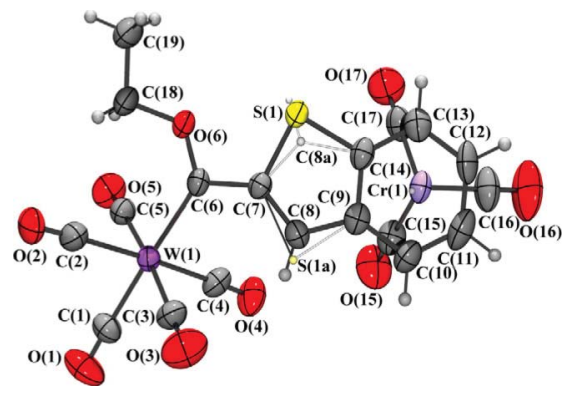

Fig. 5 ORTEP ${ }^{13}+$ POV-Ray ${ }^{14}$ drawing of the molecular structure of $\mathbf{3 b}$. Atomic displacement ellipsoids are shown at the $50 \%$ probability level. The minor positions of the disordered atoms $-\mathrm{S}(1 \mathrm{a})$ and $\mathrm{C}(8 \mathrm{a})-\mathrm{H}(8 \mathrm{a})$ are shown as small arbitrary sized spheres and with their bonds in a lighter colour.

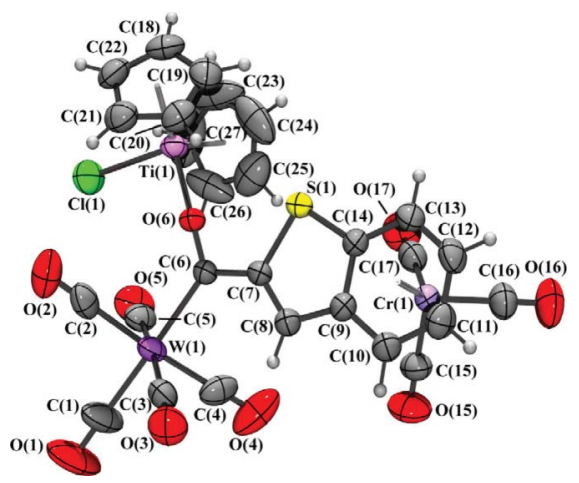

Fig. 6 ORTEP ${ }^{13}+$ POV-Ray ${ }^{14}$ drawing of the molecular structure of $\mathbf{4 b}$. Atomic displacement ellipsoids are shown at the $50 \%$ probability level.

the expense of $\mathrm{O}(6) \rightarrow \mathrm{Ti}(1) \pi$-donation, so that the contributing structures shown in Fig. 8 can be inferred, thus demonstrating the acyl and ionic character present in the titanium-oxygen bond, similar to the bonding observed in zirconoxycarbene complexes. ${ }^{21}$

The W-C(carbene) distances fall in the range 2.179(7)-2.253(9) $\AA$, which is typical for alkoxycarbene complexes of $\mathrm{W}(\mathrm{CO})_{5} \cdot{ }^{22}$ The longest tungsten-carbene carbon bond length is associated with complex $\mathbf{6 b}$, where the $\pi$-delocalisation of the ferrocene ring (Fig. 9) ${ }^{23}$ as well as inductive effects towards stabilizing the carbene carbon atom requires less back bonding from the $\mathrm{W}(\mathrm{CO})_{5}$-moiety.

The structures containing a $\mathrm{Cr}(\mathrm{CO})_{3}$-fragment $\pi$-bonded to the benzothienyl substituent $\left(\mathbf{3 b}\right.$ and $\mathbf{4 b}$ ) result in shorter $\mathrm{W}_{-}$

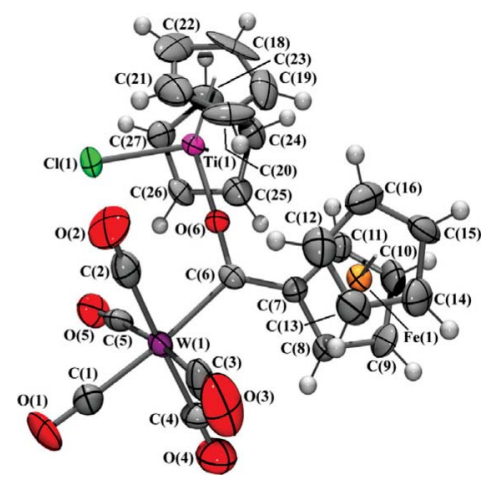

Fig. 7 ORTEP ${ }^{13}+$ POV-Ray ${ }^{14}$ drawing of the molecular structure of $\mathbf{6 b}$. Atomic displacement ellipsoids are shown at the $50 \%$ probability level.

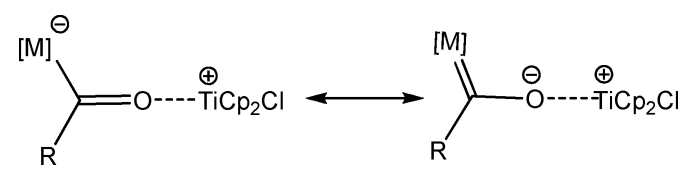

Fig. 8 Ti-O interaction for titanoxycarbene complexes.

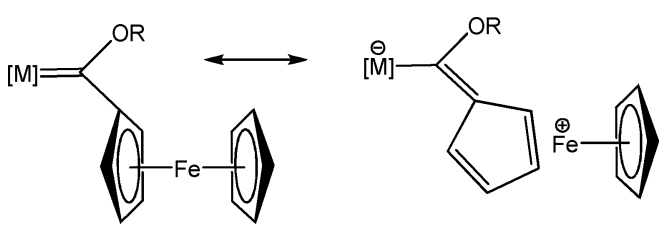

Fig. 9 Contributing structures of the ferrocenyl carbene complexes.

$\mathrm{C}$ (carbene) bond distances than the corresponding counterparts $\mathbf{1 b}$ and $\mathbf{2 b}$ without the $\pi$ - $\mathrm{Cr}(\mathrm{CO})_{3}$ group (Table 2). The $\pi$-bond of a metal to a heteroarene acts as an 'electron sink', ${ }^{24}$ disrupting the prevalent aromaticity of the ring and exerts an electron withdrawing inductive effect causing increased ring participation in carbene stabilisation. ${ }^{25}$ The $\mathrm{W}-\mathrm{C}$ (carbene) bond distances can be listed in order of increasing bond length, as a measure of the amount of back donation required from the tungsten carbonyl centre towards carbene stabilisation:

WBTCrEt 3b (2.179(7) $\AA)<$ WBTEt 1b (2.201(5) $\AA) \approx$ WBTCrTi 4b (2.207(4) ̊) < WBTTi $2 b(2.211(4) \AA) \approx W F c E t$ 5b $(2.215(4) \AA)^{10}<$ WFcTi $6 \mathbf{b}(2.253(9) \AA)$.

This order reflects the extreme cases of greater donor ability of the ferrocenyl substituent and the ionic character of the titanoxy substituent $v s$. the electron withdrawing effect of the $\pi-\mathrm{Cr}(\mathrm{CO})_{3}$ moiety and the 'less' donating ethoxy substituent. However, no clear trend about the effect of different combinations of these metal-containing substituents can be ascertained.

\section{Crystal packing}

Packing of both the chromium ${ }^{3}$ and tungsten crystal structures obtained seemed to be mostly governed by closest-packing, except in the case of $\mathbf{6 a}$ and $\mathbf{6 b}$. The previously characterised chromium ferrocenyl carbene complex 6a (Fig. 10), ${ }^{3 \mathrm{~b}}$ crystallised in the $P 2_{1} / n$ space group with one dichloromethane solvent molecule per complex molecule. The complex molecules display $\pi$-stacking 
Table 2 Selected bond lengths $(\AA)$, bond angles $\left({ }^{\circ}\right)$ and torsion angles $\left(^{\circ}\right)$ for the tungsten carbene complexes

\begin{tabular}{|c|c|c|c|c|c|}
\hline $\mathrm{W}(1)-\mathrm{C}(6)$ & $2.201(5)$ & $2.211(4)$ & $2.179(6)$ & $2.207(4)$ & $2.253(9)$ \\
\hline $\mathrm{C}(6)-\mathrm{O}(6)$ & $1.315(6)$ & $1.279(4)$ & $1.317(8)$ & $1.280(5)$ & $1.273(11)$ \\
\hline $\mathrm{O}(6)-\mathrm{C}(18) / \mathrm{O}(6)-\mathrm{Ti}(1)$ & $1.447(6)$ & $1.931(2)$ & $1.459(7)$ & $1.921(3)$ & $1.901(6)$ \\
\hline $\mathrm{W}(1)-\mathrm{C}(1)$ & $2.018(6)$ & $2.007(4)$ & $2.011(7)$ & $2.000(6)$ & $2.008(13)$ \\
\hline $\mathrm{W}(1)-\mathrm{C}(2,3,4,5)^{a}$ & $2.036(4)$ & $2.033(21)$ & $2.058(15)$ & $2.029(19)$ & $2.022(27)$ \\
\hline C(1)-W(1)-C(6) & $175.0(2)$ & $174.0(1)$ & $177.4(2)$ & $177.2(3)$ & $174.2(4)$ \\
\hline $\mathrm{O}(6)-\mathrm{C}(6)-\mathrm{C}(7)$ & $105.7(4)$ & $112.7(3)$ & $105.5(5)$ & $112.5(3)$ & $114.5(8)$ \\
\hline $\mathrm{O}(6)-\mathrm{C}(6)-\mathrm{W}(1)$ & $130.1(4)$ & $121.2(3)$ & $130.0(4)$ & $121.4(3)$ & $118.5(7)$ \\
\hline $\mathrm{C}(7)-\mathrm{C}(6)-\mathrm{W}(1)$ & $124.2(4)$ & $125.9(2)$ & $124.4(4)$ & 126.1(3) & $127.0(7)$ \\
\hline $\mathrm{C}(6)-\mathrm{O}(6)-\mathrm{C}(18) / \mathrm{C}(6)-\mathrm{O}(6)-\mathrm{Ti}(1)$ & $122.3(4)$ & $171.7(3)$ & $123.2(5)$ & $174.6(3)$ & $175.4(7)$ \\
\hline $\mathrm{C}(6)-\mathrm{C}(7)-\mathrm{S}(1) / \mathrm{C}(6)-\mathrm{C}(7)-\mathrm{C}(11)$ & $119.4(4)$ & $120.9(3)$ & $117.0(4)$ & $119.7(3)$ & $127.2(9)$ \\
\hline
\end{tabular}

${ }^{a}$ Averaged value (the errors shown are the standard deviations, $\sigma_{n-1}$, for the $n$ components averaged).

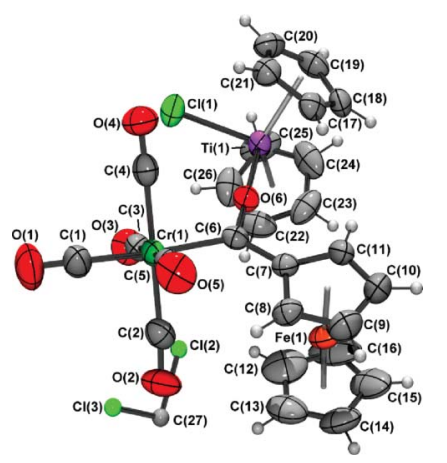

Fig. 10 Molecular structure of $6 \mathbf{a}^{3 \mathrm{~b}}$

of the ferrocenyl Cp-rings, stacked one above the other, separated by $3.584 \AA$. The corresponding tungsten complex $\mathbf{6 b}$ crystallised in the $P n a 2_{1}$ space group and no solvent inclusion is observed. In both cases, however, the crystal packing is such that pockets are formed, which in the case of $\mathbf{6 a}$ is filled with two dichloromethane molecules (Fig. 11). The cell volumes of the different structures indicate that although tungsten has a considerably larger atomic radius, the solvent inclusion increases unit cell size. For $\mathbf{6 a}$, the unit cell has a volume of $2838.5(4) \AA^{3}$, while $\mathbf{6 b}$ has a unit cell volume of 2539.2(6) $\AA^{3}$, as demonstrated in Fig. 11 (left, bottom), in which two of the solvent molecules in the crystal packing of $\mathbf{6 a}$ have been deleted from the pocket, compared to the much smaller empty space/pocket of $\mathbf{6 b}$ in Fig. 11(right, bottom).

\section{Substituent effect investigation}

An attempt was made to correlate the donor properties of the various carbene ligands in the complexes listed in Scheme 1 with respect to both the $\mathrm{C} \equiv \mathrm{O}$ stretching frequencies and bond lengths. With the aid of DFT calculations, ${ }^{26}$ the $\mathrm{A}_{1}{ }^{1}$ band, the mode associated with the stretching of the $\mathrm{C}-\mathrm{O}$ bond trans to the carbene ligand, was chosen as probe, ${ }^{27}$ as it was expected to be most affected by the electronic environment. To exclude solvent effects, solid, crystalline samples of complexes $\mathbf{3 a}$ and $\mathbf{3 b}$ (MBTCrEt); $\mathbf{4 a}$ and $\mathbf{4 b}$ (MBTCrTi); and $\mathbf{6 a}$ and $\mathbf{6 b}(\mathrm{MFcTi})(\mathrm{M}=\mathrm{Cr}, \mathrm{W})$ were obtained and solid state infrared and Raman spectra measured. The IR data displayed clearly resolved spectra, with the expected localised $C_{4 \mathrm{v}}$ pattern of the IR-active $\mathrm{A}_{1}{ }^{2}, \mathrm{~A}_{1}{ }^{1}$ and E-modes for a $\mathrm{M}(\mathrm{CO})_{5} \mathrm{~L}$-system. ${ }^{27}$ Although all four modes $\left(\mathrm{A}_{1}{ }^{2}, \mathrm{~A}_{1}{ }^{1}, \mathrm{~B}_{1}\right.$ and E) are Raman-active, only two bands were confidently observed in the Raman spectra: the $\mathrm{A}_{1}{ }^{1}$ and $\left(\mathrm{E}+\mathrm{A}_{1}{ }^{2}\right)$ bands. ${ }^{27}$ Due to accidental degeneracy, the $\mathrm{E}$ and the $\mathrm{A}_{1}{ }^{2}$ bands cannot be resolved in the solid state. ${ }^{28}$ In addition, the $\mathrm{A}_{1}{ }^{1}$ band (trans $v(\mathrm{CO})$ ) was not observed in the presence of titanoxycarbene substituents due to distortional effects, as illustrated in Fig. 12. From the crystal structures of these complexes, it can be seen that the Cl-atom of the titanoxy substituent protrudes in between two cis-CO ligands (Fig. 13). This distortion of the $C_{4 \mathrm{v}}$ symmetry can lead to loss of, or reduction of, symmetry, resulting in either localised $C_{s}$ or $C_{2 \mathrm{v}}$ symmetry which explains the disappearance of some Raman active vibrational modes.

The absence of the $\mathrm{A}_{1}{ }^{1}$ band in the Raman spectra of the titanoxy complexes as well as the significant contribution from the $\pi$-bonded $\mathrm{Cr}(\mathrm{CO})_{3}$-fragment, indicated by the DFT calculated vibrational frequencies, therefore precluded the use of this vibrational mode as a probe for substituent effects. For $\mathrm{M}(\mathrm{CO})_{5} \mathrm{~L}$ molecules, three IR active $v\left(\mathrm{M}-\mathrm{C}_{\text {carbonyl }}\right)$ vibrations occur $\left(2 \mathrm{~A}_{1}+\right.$ E) in the far-infrared region, usually in the range $380-500 \mathrm{~cm}^{-1} .^{29}$ These metal-carbon stretching vibrations fall within range of the chromium tricarbonyl-fragment $\mathrm{M}-\mathrm{C}_{\text {carbonyl }}$ and other $\mathrm{M}-\mathrm{L}$ vibrations, e.g. Ti-Cl etc. ${ }^{30}$ As far as could be ascertained, the only $\mathrm{M}-$ $\mathrm{C}_{\text {carbene }}$ frequencies reported to date are for $\mathrm{CH}_{2}$-carbene ligands, ranging from 625 to $820 \mathrm{~cm}^{-1}$ for iron ${ }^{31}$ and osmium ${ }^{32}$ complexes, respectively, and for vinylidene complexes of rhodium, trans$\left[\mathrm{RhX}(=\mathrm{C}=\mathrm{HR})\left(\mathrm{PR}_{3}^{\prime}\right)_{2}\right]$ where $v(\mathrm{Rh}=\mathrm{C})$ ranges from 550 to $580 \mathrm{~cm}^{-1} \cdot{ }^{33}$ For Fischer carbenes of the type $\left[(\mathrm{CO})_{5} \mathrm{M}=\mathrm{C}(\mathrm{OR}) \mathrm{R}^{\prime}\right]$, the only carbene-associated bands reported to our knowledge were attributed to $v\left(\mathrm{C}_{\text {carbene }}-\mathrm{OR}\right) .{ }^{34} \mathrm{DFT}$ calculations were therefore 


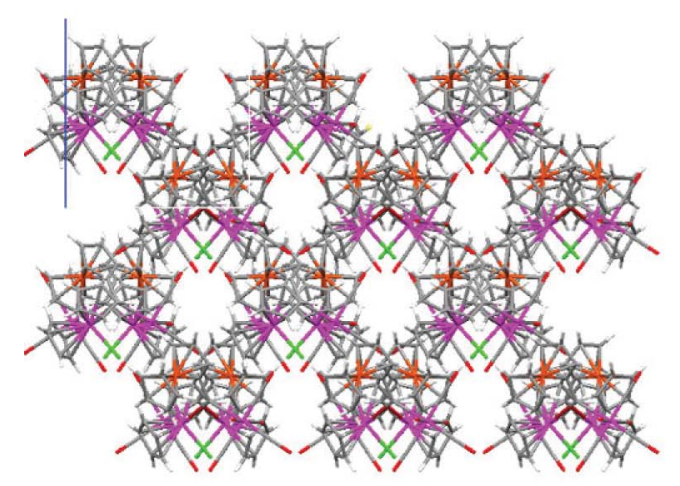

Complex 6a

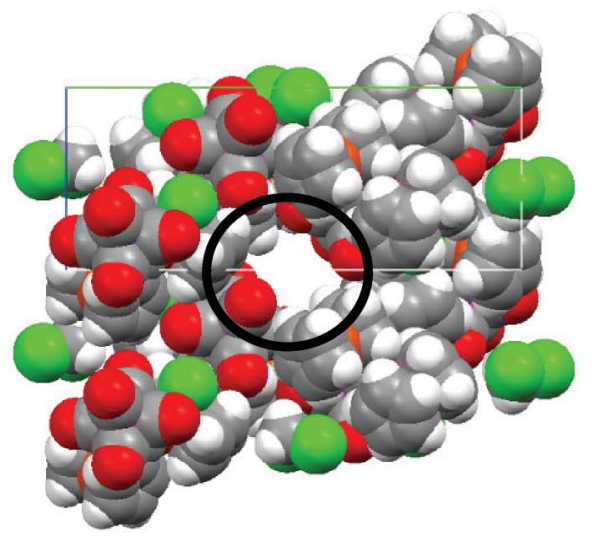

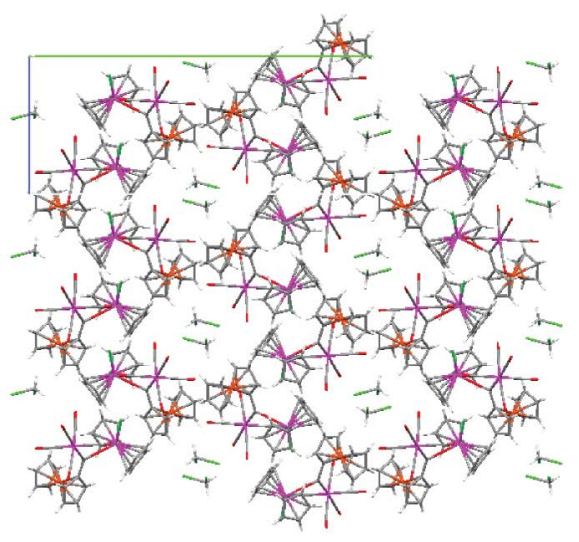

Complex 6b

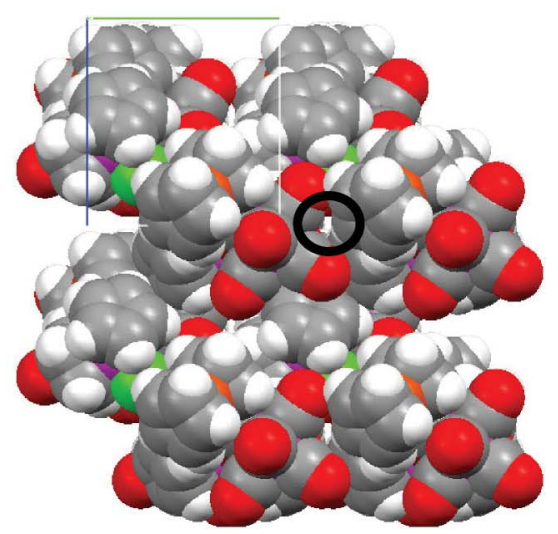

Fig. 11 Mercury ${ }^{38}$ views along the $a$-axis to indicate presence of pocket/channel of $\mathbf{6 a}$ and $\mathbf{6} \mathbf{b}$, as well as space-filled representations (from which solvent molecules of $\mathbf{6 a}$ have been deleted).

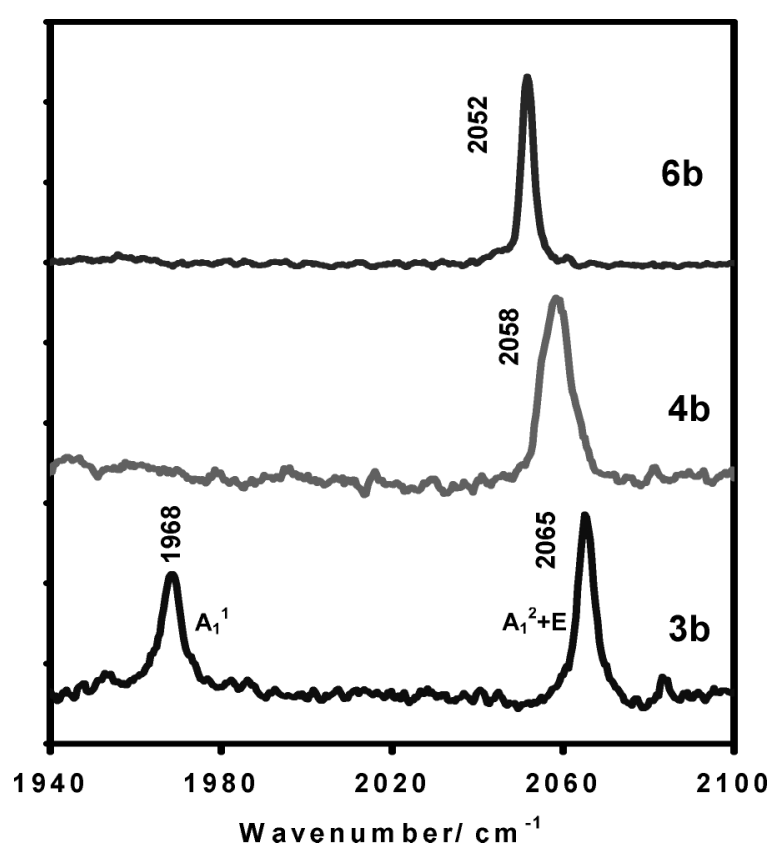

Fig. $12 v(\mathrm{CO})$ region of the Raman spectra of complexes $\mathbf{2 b}, \mathbf{4 b}$ and $\mathbf{6 b}$, showing the disappearance of the $\mathrm{A}_{1}{ }^{1}$ band due to distortion effect of $-\mathrm{TiCp}_{2} \mathrm{Cl}$ substituent.

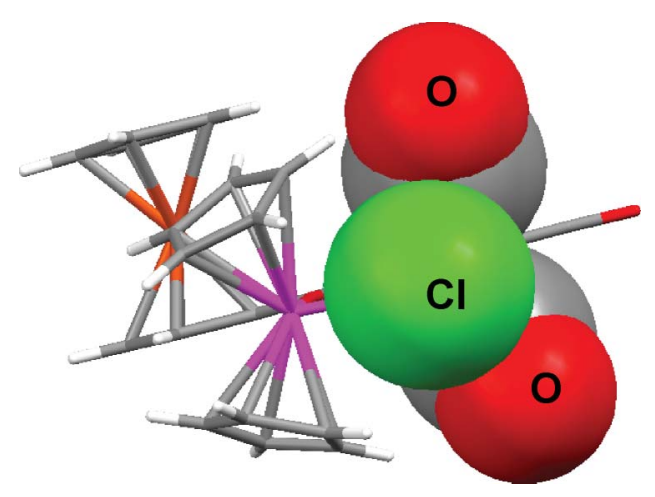

Fig. 13 Mercury ${ }^{39}$ space-filled representation of the Cl-atom protruding between two cis-CO ligands of complex $\mathbf{6} \mathbf{b}$.

employed to assist in the assignment of a $\mathrm{M}=\mathrm{C}_{\text {carbene }}$ stretching frequency. However, the modelled data indicated that no pure $v\left(\mathrm{M}=\mathrm{C}_{\text {carbene }}\right)$ mode exists. Instead, a bending vibration or scissor mode could be identified from the calculations. A representative overlay of the measured experimental IR and Raman spectra and the calculated spectra used for assignment is demonstrated in Fig. 14. The IR spectra illustrated in Fig. 14 also display the ring- $\mathrm{C}-\mathrm{H}$ deformation $\delta\left(\mathrm{C}_{\text {aromatic }}-\mathrm{H}\right)$ modes. ${ }^{35}$ The $\delta\left(\mathrm{CC}_{\text {carbene }} \mathrm{O}\right)$ scissor mode consists of a 'stretching' displacement of the carbene carbon atom towards the central metal atom, with contribution 


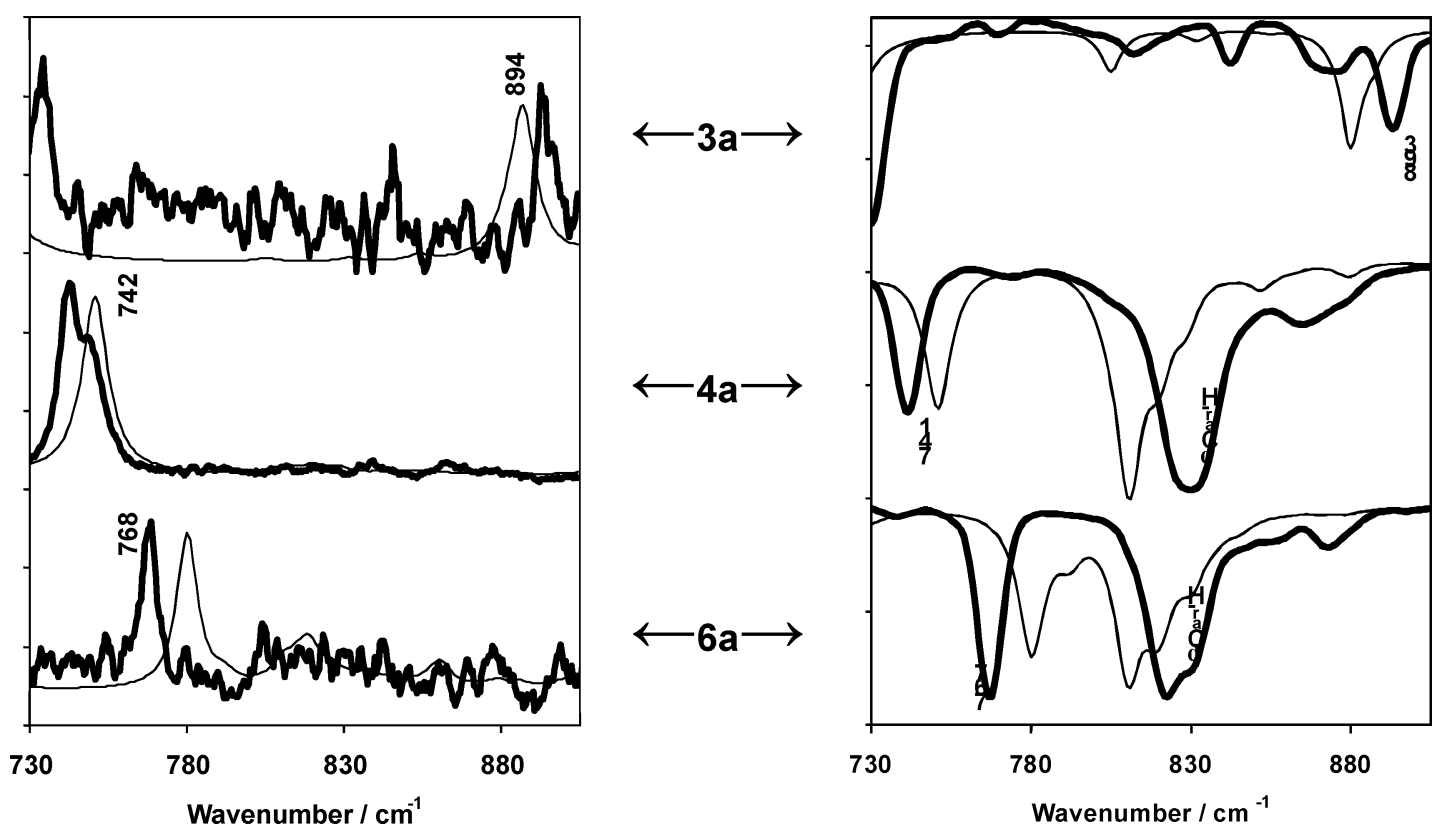

Fig. 14 Comparative experimental (bold) and unscaled calculated (thin line) IR (left) and Raman (right) spectra of the $\delta(\mathrm{CC}$ carbene $\mathrm{O}$ ) scissor mode for the chromium complexes.

from the carbene carbon substituents, as depicted in Fig. 15. This carbene ligand associated band was observed at higher wavenumbers than the $v\left(\mathrm{M}-\mathrm{C}_{\text {carbonyl }}\right)$ bands in both the solid state IR and Raman spectra. The scissor mode-related band and the other substituent-influenced band, the $\mathrm{A}_{1}{ }^{1} v(\mathrm{CO})$ mode, are assigned in Table 3. The carbene ligand associated $\delta\left(\mathrm{CC}_{\text {carbene }} \mathrm{O}\right)$ band displayed the highest energy for the $\eta^{6}$-2-benzo[b]thienyl chromium tricarbonyl ethoxy-substituted carbene complexes, corresponding to the shortest $\mathrm{M}=\mathrm{C}_{\text {carbene }}$ bond lengths listed in Table 2. This supports the supposition that greater back-donation from the metal is necessary for a ring substituent $\pi$-bonded to a $\mathrm{Cr}(\mathrm{CO})_{3}$-fragment that acts as an electron sink, minimising ringinvolvement towards carbene stabilisation. The acyl character of the carbene oxygen atom of the titanoxy substituents could also be assumed to require less metal donation to the carbene carbon p orbital, compared to that of the ethoxycarbenes. However, when the titanoxy substituent is kept constant and the effect of the $\eta^{6}$-2-benzo[b]thienyl chromium tricarbonyl $v s$. the ferrocenyl substituent is compared, lower $\delta\left(\mathrm{CC}_{\text {carbene }} \mathrm{O}\right)$ frequencies are obtained for the $\left[\mathrm{Cr}(\mathrm{CO})_{3}\left(\eta^{6}-2\right.\right.$-benzo[b]thienyl)]-complexes even though $\mathrm{Fc}$ is the better donor. This could be ascribed to the greater bulk of the aforementioned substituent compared to that of Fc. The steric

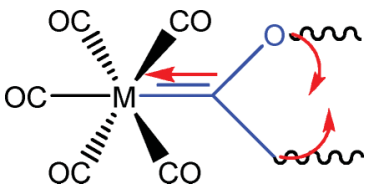

Fig. 15 A schematic representation of the $\delta\left(\mathrm{CC}_{\text {carbene }} \mathrm{O}\right)$ scissor mode.

bulk contributes to the moment of inertia of the scissor mode, an indication that both steric and electronic effects should be taken into account. The calculated force constants of the vibrations were also considered, but followed the same order of magnitude trends as the actual vibrational frequencies.

\section{Molecular orbital analysis}

Even though calculated atomic charges indicated that the carbene carbon atom is less positive than the carbonyl carbons, ${ }^{36}$ the carbene carbon is known to be the preferred site for nucleophilic attack and charge does not determine reactivities. This reactivity was explained by frontier orbital control, ${ }^{37}$ emphasising the importance of a compound's HOMO or LUMO in determining which sites in the molecule will be most susceptible to attack by an

Table 3 Experimental IR and Raman data of substituent influenced vibrational bands $\left(\mathrm{cm}^{-1}\right)$

\begin{tabular}{|c|c|c|c|c|c|c|}
\hline & IR & $\mathrm{R}$ & IR & $\mathrm{R}$ & IR & $\mathrm{R}$ \\
\hline$v(\mathrm{CO}) \mathrm{A}_{1}{ }^{1}$ & 1963 & 1968 & 1934 & - & 1921 & - \\
\hline Assignment & 3b WBTCrET & & 4b WBTCrTi & & 6b WFcTi & \\
\hline & IR & $\mathrm{R}$ & IR & $\mathrm{R}$ & IR & $\mathrm{R}$ \\
\hline$v(\mathrm{CO}) \mathrm{A}_{1}{ }^{1}$ & 1960 & 1968 & 1913 & - & 1928 & - \\
\hline$\delta\left(\mathrm{CC}_{\text {carbene }} \mathrm{O}\right)$ & 895 & 895 & 746 & 748 & 774 & 774 \\
\hline
\end{tabular}

IR: infrared, R: Raman 
Table 4 Calculated molecular orbital energy differences $(\mathrm{eV})$ and electrophilicity indices $(\mathrm{eV})$

\begin{tabular}{|c|c|c|c|c|c|c|}
\hline & 1a & 2a & 3a & $4 a$ & $5 a$ & $6 \mathbf{a}$ \\
\hline (LUMO) - (HOMO) & 3.3632 & 2.9414 & 2.6176 & 2.7085 & 3.6932 & 3.1315 \\
\hline$($ LUMO + 1) $-($ LUMO $)$ & 1.5374 & 0.3320 & 1.7387 & 0.4827 & 1.0198 & 0.0460 \\
\hline & $1 \mathrm{~b}$ & $2 b$ & $\mathbf{3 b}$ & $4 \mathrm{~b}$ & $5 \mathbf{b}$ & $6 b$ \\
\hline (LUMO) - (HOMO) & 3.1335 & 2.7278 & 2.5308 & 2.5466 & 3.4818 & 3.0320 \\
\hline$(\mathrm{LUMO}+1)-(\mathrm{LUMO})$ & 1.0941 & 0.3744 & 1.3118 & 0.5989 & 0.6356 & 0.0506 \\
\hline$\omega$ & 3.7613 & 3.9969 & 4.8946 & 4.7390 & 2.8401 & 3.2709 \\
\hline
\end{tabular}

electrophile or nucleophile. ${ }^{38}$ A striking result of the literature MO calculations on the carbene complexes was the marked separation of the LUMO from all of the other molecular orbitals. ${ }^{37}$ The energy differences between the LUMO's and the next-closest lying molecular orbitals were calculated, (Table 4) to determine if the isolation of the LUMO energy level from the other molecular orbitals calculated also determined carbene ligand electrophilicity. Another way to evaluate the electrophilicity of these complexes is to calculate the electrophilicity index, $\omega,{ }^{40}$ for each complex (Table 4), using the expression,

$$
\omega \equiv \mu^{2} / \eta
$$

where $\mu$ is the chemical potential ${ }^{41}$ and $\eta$ is the hardness. ${ }^{42}$ These values are related to the molecular orbital energies, and the chemical potential and hardness can be calculated from the HOMO and LUMO orbital energies using the following approximate expressions:

$$
\begin{gathered}
\mu=\left(E_{\mathrm{LUMO}}+E_{\mathrm{HOMO}}\right) / 2 \\
\eta=E_{\mathrm{LUMO}}-E_{\mathrm{HOMO}}
\end{gathered}
$$

When electrophilic indices were calculated by Frenking et $a l^{4 a}$ for Fischer carbene complexes, it was found that $\pi$-donor substituents reduce the electrophilicity of the complexes, as a result of the acceptor orbital in the carbene becoming occupied by $\pi$-donation. The values listed in Table 4 appear to adhere to the above statement. Thus for every fixed $\left[\mathrm{M}(\mathrm{CO})_{5}\{\mathrm{C}(\mathrm{OX})(\right.$ aryl $\left.)\}\right]$ $\left(\mathrm{X}=\mathrm{Et}\right.$ or $\left.\mathrm{TiCp}_{2} \mathrm{Cl}\right)$, the electrophilicity increases following the order $\mathrm{Fc}<2$-benzothienyl $<2-\eta^{6}$-benzo[ $\left.b\right]$ thienyl chromium tricarbonyl. This once again demonstrates the donating properties of the ferrocenyl group, and the largest electrophilicities of the $\pi$-bonded $\mathrm{Cr}(\mathrm{CO})_{3}$-substituted carbene complexes in line with the acceptor character of these substituents. Due to the greatly differing nature of these substituents, a greater impact on the carbene electrophilicity is effected by these ring-substituents, compared to the results of Connor et $a .^{6}{ }^{6}$ where the nature of the heteroatom substituent, rather than the arene-substituent or the metal, more strongly influenced the electronic nature of the carbene carbon atom. In the case of the ferrocenyl and benzothienyl complexes, higher electrophilicity indices were calculated for the titanoxy analogues. For the $\left[\mathrm{Cr}(\mathrm{CO})_{3}\left(2-\eta^{6}-\mathrm{BT}\right)\right]$-substituted complexes, higher $\omega$-values were obtained for the ethoxycarbene complexes, as expected from previous results where the donating character of the acyl-like oxygen of the titanoxycarbenes were demonstrated.

\section{Cyclic voltammetry}

For carbene complexes of the type $\left[\mathrm{M}(\mathrm{CO})_{5} \mathrm{C}(\mathrm{X}) \mathrm{R}\right](\mathrm{M}=\mathrm{Cr}$, Mo and $\mathrm{W})$, cyclic voltammetry showed that the primary oxidation of these complexes corresponded to a one electron transfer. ${ }^{43}$ The value of $E_{\frac{1}{2}}$ was not greatly influenced by $\mathrm{R}$ for a specific $\mathrm{X}$-group, provided that $\mathrm{R}$ was an organic fragment. But if $\mathrm{R}=$ Fc, redox potentials decreased by more than $200 \mathrm{mV}$. Similarly for decreasing donor strength of $\mathrm{X}$ into $\mathrm{C}_{\text {carbene }} \mathrm{p}$ orbital, increased redox potentials were observed.

Considering the above information, an attempt was made to establish a qualitative contribution of the different combinations of accepting/accepting, accepting/donating, donating/accepting and donating/donating substituents on the carbene ligands. Thus the substituents could be classified (for the $\mathrm{X}$ and $\mathrm{R}$ carbene substituents, respectively) as follows: $\mathrm{X}=\mathrm{OTiCp} \mathrm{Cl}_{2} \mathrm{Cl}$ ('donating'), $\mathrm{X}=\mathrm{OEt}$ (less donating), and $\mathrm{R}=2-\eta^{6}$-benzo $[b]$ thienyl chromium tricarbonyl (accepting), $\mathrm{R}=$ ferrocenyl (donating) and $\mathrm{R}=2$ benzothienyl (less donating).

The electrochemical data obtained for the cyclic voltammograms performed in $\mathrm{CH}_{2} \mathrm{Cl}_{2}$ solvent at low temperature $\left(-75^{\circ} \mathrm{C}\right)$ are listed in Table 5.

For the chromium complexes, all reductions observed were irreversible, whereas the first reduction wave of the tungsten compounds was reversible or partially reversible. For both the

Table 5 Voltammetric data (V)

\begin{tabular}{lllllllll}
\hline & $\mathbf{1 a}$ & $\mathbf{2 a}$ & $\mathbf{3 a}$ & $\mathbf{4 a}$ & $\mathbf{6 a}$ & $\mathbf{1 b}$ & $\mathbf{2 b}$ & $\mathbf{4 b}$ \\
\hline Oxidation $E_{\frac{1}{2}}$ & +0.97 & +0.74 & +1.00 & +0.93 & +0.84 & $+1.19^{c}$ & $+1.03^{c}$ & $+1.11^{c}$ \\
Reduction $E_{\mathrm{c}}{ }^{b}$ & -1.21 & -0.95 & -1.09 & -0.88 & -1.05 & -1.03 & -1.05 & -1.10 \\
& & & & & & & & -0.71
\end{tabular}

${ }^{a} 1.0 \mathrm{~mm}$ [carbene complex] in $\mathrm{CH}_{2} \mathrm{Cl}_{2} / 0.10 \mathrm{M} \mathrm{Bu}_{4} \mathrm{NPF}_{6}$ under $\mathrm{N}_{2}(\mathrm{~g})$ at $-75^{\circ} \mathrm{C}$. The working electrode was a $1.0 \mathrm{~mm}$ diameter platinum disk, and the scan rate was $0.50 \mathrm{~V} \mathrm{~s}^{-1}$. A ferrocene internal standard had $E_{\frac{1}{2}}=+0.52 \mathrm{~V}^{b} E_{\mathrm{c}}=$ peak potential of irreversible cathodic waves, or first reduction wave of reversible waves ${ }^{c}$ These values correspond to the irreversible anodic wave peak potential $E_{\mathrm{a}}$ of the tungsten complexes. 
chromium and tungsten complexes, the ethoxy substituted complexes only showed one cathodic wave, while the cyclic voltammograms of the titanoxycarbene complexes displayed several waves. The peak potentials of reductions listed in Table 5 are ascribed to carbene ligand-centred reductions. For monometallic chromium complexes only one reversible anodic wave, corresponding to oxidation of the pentacarbonyl metal centre, is observed. The same is true for the tungsten complexes, although the oxidation waves are only partially reversible.

The complexes containing a second metal moiety, either Fc or 2$\mathrm{BTCr}(\mathrm{CO})_{3}$, displayed another oxidation wave at lower potential, showing that the two metal moieties in each complex function as separate, localised redox centres, in contrast to results obtained previously for ferrocenyl carbene complexes. ${ }^{44}$ This implies that a direct comparison of substituent effects on the pentacarbonyl metal can be made, as it is not an electronically delocalised system. A more positive potential for $\mathbf{3 a}$ is obtained than for 1a, due to the electron withdrawing effect of the $\mathrm{Cr}(\mathrm{CO})_{3}$-fragment in $\mathbf{3 a}$, decreasing the ease of oxidation. This was also found to be valid for titanoxycarbene complex 4a vs. 2a.

In turn, when the -OEt $v s$. $-\mathrm{OTiCp}{ }_{2} \mathrm{Cl}$ fragments are compared, the increased donating character of the titanoxy fragment reflects in the lower oxidation potentials obtained for these complexes 2a and $\mathbf{4 a}$ in relation to their ethoxy counterparts $1 \mathbf{a}$ and $\mathbf{3 a}$.

\section{Conclusions}

Obtaining information directly regarding substituent effects from the preliminary vibrational investigation proved non-trivial. The use of Raman spectroscopy $v s$. IR to monitor structural changes due to symmetry breaking was clearly shown from the disappearance of the Raman-active $\mathrm{A}_{1}{ }^{1}$ band. In combination with modelling data, the novel assignment of the Raman/IR-active $\delta\left(\mathrm{CC}_{\text {carbene }} \mathrm{O}\right)$ band as a promising probe for substituent effect, was achieved.

The effect of both the heteroatom substituent as well as the (hetero)arene substituent, and in addition, different combinations of the above could be qualitatively gauged.

With the introduction of metal-containing fragments on both carbene substituents, modification of the electronic and steric nature of the carbene ligand can be effected by both the heteroatom and the (hetero)aryl substituent, in contrast with previous studies where organic fragments only were utilized. ${ }^{6,43}$

\section{Acknowledgements}

The authors gratefully acknowledge Prof. DA Sweigart for the use of his electrochemistry equipment at Brown University, Rhode Island and for his valuable discussions on the voltammetric results.

\section{References}

1 (a) J. C. Garrison, R. S. Simons, C. A. Tessier and W. J. Youngs, J. Organomet. Chem., 2003, 673, 1-4; (b) I. Fernández, M. J. Mancheño, M. Gómez-Gallego and M. A. Sierra, Org. Lett., 2003, 5, 1237-1240. 2 M. A. Sierra, Chem. Rev., 2000, 100, 3591-3638.

3 (a) D. I. Bezuidenhout, S. Lotz, M. Landman and D. C. Liles, Inorg. Chem., 2011, 50, 1521-1533; (b) D. I. Bezuidenhout, E. van der Watt, D. C. Liles, M. Landman and S. Lotz, Organometallics, 2008, 27, 24472456.
4 (a) M. Cases, G. Frenking, M. Duran and M. Sol, Organometallics, 2002, 21, 4182-4191; (b) A. Krapp and G. Frenking, J. Am. Chem. Soc., 2008, 130, 16646-16658; (c) A. Krapp, K. K. Pandey and G. Frenking, J. Am. Chem. Soc., 2007, 129, 7596-7610; (d) G. Frenking, M. Sola and S. F. Vyboishchikov, J. Organomet. Chem., 2005, 690, 6178-6204; (e) M. A. Sierra, I. Fernández and F. P. Cossío, Chem. Commun., 2008, 4671-4682; $(f)$ M. L. Lage, I. Fernández, M. J. Mancheño and M. A. Sierra, Inorg. Chem., 2008, 47, 5253-5255; $(\mathrm{g}) \mathrm{D}$. M. Andrada, M. E. Zoloff Michoff, I. Fernández, A. M. Granados and M. A. Sierra, Organometallics, 2007, 26, 5854-5858.

5 (a) K. H. Dötz, Angew. Chem., Int. Ed. Engl., 1975, 14, 644-645; (b) C. F. Bernasconi, M. Ali and F. Lu, J. Am. Chem. Soc., 2000, 122, 2183.

6 (a) J. A. Connor and E. M. Jones, J. Chem. Soc. A, 1971, 12, 1974; (b) J. A. Connor, E. M. Jones, E. W. Randall and E. Rosenburg, J. Chem. Soc., Dalton Trans., 1972, 22, 2419-2424.

7 H. Meerwein, Org. Synth., 1966, 46, 113-115.

8 E. J. Zaiko, L. Lipman, Jr., G. A. Moser and M. D. Rausch, J. Organomet. Chem., 1970, 23, 185-192.

9 R. W. Fish and M. Rosenblum, J. Org. Chem., 1965, 30, 1253 1254.

10 (a) J. A. Connor and J. P. Lloyd, J. Chem. Soc., Dalton Trans., 1972, 1470-1476; (b) L. F. C. de la Cruz, M. C. Ortega-Alfaro, J. G. Lopez-Cortez, R. A. Toscano, C. Alvarez-Toledano and H. Rudler, $J$. Organomet. Chem., 2005, 690, 2229-2237.

11 SAINT+ Version 6.45 SADABS Version 2.10 SHELXTS and SHELXTL Version 6.14, Bruker AXS Inc, Madison, W1, USA, 2001.

12 G. M. Sheldrick, Acta Crystallogr., Sect. A: Found. Crystallogr., 2008, A64, 112-122.

13 L. L. Farrugia, J. Appl. Crystallogr., 1997, 30, 565.

14 C. J. Cason, POV-RAY for Windows. Version 3.6. Persistence of Vision, Raytracer Pty. Ltd., Victoria, Australia 2004 URL: http://www.povray.org.

15 M. J. Frisch, G. W. Trucks, H. B. Schlegel, G. E. Scuseria, M. A. Robb, J. R. Cheeseman, J.A. Montgomery Jr, T. Vreven, K. N. Kudin, J. C. Burant, J. M. Millam, S. S. Iyengar, J. Tomasi, V. Barone, B. Mennucci, M. Cossi, G. Scalmani, N. Rega, G. A. Petersson, H. Nakatsuji, M. Hada, M. Ehara, K. Toyota, R. Fukuda, J. Hasegawa, M. Ishida, T. Nakajima, Y. Honda, O. Kitao, H. Nakai, M. Klene, X. Li, J. E. Knox, H. P. Hratchian, J. B. Cross, V. Bakken, C. Adamo, J. Jaramillo, R. Gomperts, R. E. Stratmann, O. Yazyev, A. J. Austin, R. Cammi, C. Pomelli, J. W. Ochterski, P. Y. Ayala, K. Morokuma, G. A. Voth, P. Salvador, J. J. Dannenberg, V. Zakrzewski, S. Dapprich, A. D. Daniels, M. C. Strain, O. Farkas, D. K. Malick, A. D. Rabuck, L/ Raghavachari, J. B. Foresman, J. V. Ortiz, Q. Cui, A. G. Baboul, S. Clifford, J. Cioslowski, B. B. Stefanov, G. Liu, A. Liashenko, P. Piskorz, I. Komaromi, R. L. Martin, D. J. Fox, T. Keith, M. A. Al-Laham, C. Y. Peng, A. Nanayakkara, M. Challacombe, P. M. W. Gill, B. Johnson, W. Chen, M. W. Wong, C. Gonzalez and J. A. Pople, Gaussian 03, revision C.02; Gaussian Inc: Wallingford CT, 2004.

16 (a) A. D. Becke, J. Chem. Phys., 1993, 98, 5648-5652; (b) C. Lee, W. Yang and R. G. Parr, Phys. Rev. B, 1998, 37, 785-789; (c) S. H. Vosko, L. Wilk and M. Nusair, Can. J. Phys., 1980, 58, 1200.

17 P. J. Hay and W. R. Wadt, J. Chem. Phys., 1985, 82, 299-311.

18 J. W. McIver and A. K. Komornicki, J. Am. Chem. Soc., 1972, 94, $2625-2633$

19 G. A. Zhurko and D. A. D. A. Zhurko, Chemcraft, Version 1.5 (build 282), 2007.

20 J. C. Huffman, K. G. Moloy, J. A. Marsella and K. G. Caulton, J. Am. Chem. Soc., 1980, 102, 3009-3014.

21 G. Erker, Angew. Chem., Int. Ed. Engl., 1989, 28, 397-412.

22 K. H. Dötz, H. Fischer, P. Hofmann, F. R. Kreissl, U. Schubert and $\mathrm{K}$. Weiss, Transition metal carbene complexes, VCH Verlag Chemie, Weinheim, 1983.

23 J. A. Connor and J. P. Lloyd, J. Chem. Soc., Dalton Trans., 1972, 14701476.

24 A. Mangini and F. Taddei, Inorg. Chim. Acta, 1968, 2, 8-11.

25 (a) J. D. Holmes, D. A. K. Jones and R. Pettit, J. Organomet. Chem., 1965, 4, 324-331; (b) W. S. Trahanovsky and D. K. Wells, J. Am. Chem. Soc., 1969, 91, 5870-5871; (c) R. S. Bly and R. C. Strickland, J. Am. Chem. Soc., 1970, 92, 7459-7461; (d) D. K. Wells and W. S. J. Trahanovsky, J. Am. Chem. Soc., 1970, 92, 74617463.

26 D. G. Gusev, Organometallics, 2009, 28, 763-770.

27 D. M. Adams, Metal-Ligand and Related Vibrations, Edward Arnold Publishers Ltd, London, 1967, 98. 
28 I. S. Butler, A. Garcia-Rodrigues, K. R. Plowman and C. F. Shaw II, Inorg. Chem., 1976, 15, 2602-2609.

29 M. Spolini, L. Bencivenni, A. Farina, B. Martini and S. N. Cesaro, J. Mol. Struct., 1980, 65, 105-113.

30 M. Y. Darensbourg and D. J. Darensbourg, Inorg. Chem., 1970, 9, 32-39.

31 S.-C. Chang, R. H. Hauge, Z. H. Kafafi, J. L. Margrave and W. E. Billups, J. Am. Chem. Soc., 1988, 110, 7975-7980.

32 T. Fischer, C. Fickert, A. Grubeck, W. Kiefer, B. Weber, W. Stüer and H. Werner, Asian Chem. Lett., 1998, 2, 83-91.

33 D. Moigno, W. Kiefer, B. Callejas-Gaspar, J. Gil-Rubio and H. Werner, New J. Chem., 2001, 25, 1389-1397.

34 D. Lin-Vien, N. B. Colthup, W. G. Fateley and J. G. Graselli, The handbook of infrared and Raman characteristic frequencies of organic molecules, Academic Press, New York, 1990, 286.

35 A. D. Rooney, J. J. McGarvey and K. C. Gordon, Organometallics, 1995, 14, 107-113.

36 W. B. Perry, T. F. Schaaf, W. L. Jolly, L. J. Todd and D. L. Cronin, Inorg. Chem., 1974, 13, 2038-2039.
37 (a) T. J. Block, R. F. Fenske and C. P. Casey, J. Am. Chem. Soc., 1976, 98, 441-443; (b) H. Nakatsuji, J. Ushio and T. Yonezawa, J. Am. Chem. Soc., 1983, 105, 426-434; (c) H. C. Foley, L. M. Strubinger, T. S. Targos and G. L. Geoffrey, J. Am. Chem. Soc., 1983, 105, 3064-3073.

38 (a) K. Fukui and H. Fujimoto, Bull. Chem. Soc. Jpn., 1969, 42, 3399; (b) G. Klopman and R. F. Hudson, Theor. Chim. Acta, 1967, 8, 165.

39 C. F. Macrae, I. J. Bruno, J. A. Chisholm, P. R. Edgington, P. McCabe, E. Pidcock, L. Rodriguez-Monge, R. Taylor, J. van de Streek and P. A. Wood, J. Appl. Crystallogr., 2008, 41, 466-470.

40 R. G. Parr, L. v. Szentpály and S. Liu, J. Am. Chem. Soc., 1999, 121, 1922-1924.

41 R. G. Parr and W. Yang, Density-Functional Theory of Atoms and Molecules, Oxford University Press, New York, 1989.

42 R. G. Pearson, Chemical Hardness, Wiley-VCH, Oxford, 1997.

43 M. K. Lloyd, J. A. McCleverty, D. G. Orchard, J. A. Connor, M. B. Hall, I. H. Hillier, E. M. Jones and G. K. G. K. McEwen, J. Chem. Soc., Dalton Trans., 1973, 1743-1747.

44 L. Meca, D. Dvořák, J. Ludvík, I. Cśařová and P. Stěpnička, Organometallics, 2004, 23, 2541-2551. 